\title{
In Situ Cultured Bacterial Diversity from Iron Curtain Cave, Chilliwack, British Columbia, Canada
}

\author{
Soumya Ghosh ${ }^{1}$, Elise Paine ${ }^{1, \dagger}$, Rob Wall ${ }^{2}$, Gabrielle Kam ${ }^{1}$, Tanna Lauriente ${ }^{1}$, \\ Pet-Chompoo Sa-ngarmangkang ${ }^{1, \ddagger}$, Derrick Horne ${ }^{3}$ and Naowarat Cheeptham ${ }^{1, *}$ \\ 1 Department of Biological Sciences, Faculty of Science, Thompson Rivers University, 900 McGill Road, \\ Kamloops, BC V2C 08C, Canada; sghosh@tru.ca (S.G.); elisepaine25@hotmail.com (E.P.); \\ gabrielle.kam18@gmail.com (G.K.); laurientet13@mytru.ca (T.L.); p.sangarmangkang@gmail.com (P.S.) \\ 2 Chilliwack River Valley Cavers, Yarrow Station Main, P.O. Box 4023, Chilliwack, BC V2R 5H8, Canada; \\ crvc@nicbc.ca \\ 3 Bio-Imaging Facility, University of British Columbia, RM 64 George Cunningham Building, 2146 East Mall, \\ Vancouver, BC V6T 1Z4, Canada; derrick.horne@botany.ubc.ca \\ * Correspondence: ncheeptham@tru.ca \\ + Current address: LifeLabs, Department of Microbiology and Infectious Diseases, 7455, 130th Street, Surrey, \\ BC V3W1H8, Canada. \\ $\ddagger$ Current address: Department of Biology, Biological Science Building, University of British Columbia, \\ 6270 University Blvd, University Endowment Lands, Vancouver, BC V6T 1Z4, Canada.
}

Received: 28 June 2017; Accepted: 18 August 2017; Published: 29 August 2017

\begin{abstract}
The culturable bacterial diversity from Iron Curtain Cave, Chilliwack, British Columbia, Canada was examined. Sixty five bacterial isolates were successfully cultivated, purified, and identified based on 16S rRNA gene sequencing. Four distinguishable phyla, i.e., Actinobacteria (44.61\%), Proteobacteria (27.69\%), Firmicutes (20\%) and Bacteroidetes $(7.69 \%)$ were identified. Arthrobacter (21.53\%) was identified as the major genus, followed by Sporosarcina $(9.23 \%)$, Stenotrophomonas (9.23\%), Streptomyces (6.15\%), Brevundimonas (4.61\%), and Crocebacterium (2.8\%). Noteworthy, $12.3 \%$ of the population was recognized as unidentified bacteria. The isolates were evaluated for their potential antimicrobial activities against multidrug resistant microbial strains. Two species of the genus Streptomyces exhibited a wide range of antimicrobial activities against multidrug resistance (MDR) strains of Escherichia coli and Pseudomonas spp. along with non-resistant strains of Staphylococcus aureus and E. coli. However, all of the antimicrobial activities were only observed when the isolates were grown at $8^{\circ} \mathrm{C}$ in different media. To the best of our knowledge, this is the first study conducted on the Iron Curtain Cave's bacterial diversity, and reveals some bacterial isolates that have never been reported from a cave. Bacterial isolates identified with antimicrobial properties demonstrated that the Iron Curtain Cave can be further considered as a potential habitat for antimicrobial agents.
\end{abstract}

Keywords: cave characteristics; cave bacterial diversity; 16S rRNA gene; antimicrobial activities

\section{Introduction}

The study of cave microbiomes has been at the center of biologists' attention for the last few decades, both because of the microbial diversity in cave habitats and the potential for the production of unique primary and secondary metabolites, which differ from those found in other extreme habitats [1]. Numerous microbial diversity studies have been performed using the samples taken from the sediment deposits found on the walls and ceilings of caves, aquatic sediments, and on speleothem surfaces [2]. These cave microorganisms were thought to be introduced from the surface by air currents, sediments, water, animal, or human vectors, which was unusual for subsurface habitats [3]. However, the cave microbial composition varied between the types and the nature of caves [4-6]. 
The cave microbiomes contain a wide array of bacterial groups such as Pseudonocardinae, Chromatiales, Xanthomonadales, Acidobacteria, Actinobacteria, Cyanobacteria, Ktedonobacteria, Alphaproteobacteria, Betaproteobacteria, Gammaproteobacteria, Deltaproteobacteria, Etaproteobacteria [3,7-9] and fungi such as Penicillium, Aspergillus, Trichoderma, Microdiplodia, Cladosporium spp., Mucor spp. [10-12]. However, the cultivation of these microorganisms in the laboratory environment was proven to be challenging, as the typical incubation temperature often ranged between $25-37{ }^{\circ} \mathrm{C}$. Moreover, the rich formulated media typically used to culture chemoorganotrophs could not support the growth of these microbes that were believed to be oligotrophs [1,2]. Later on, the scientists realized that most of these microbes are adapted to nutrient-poor, starving environments where they scavenge to obtain food. Therefore, a number of cultivation media at normal and diluted strengths such as R2A, Hickey-Tresner agar, humic acid-vitamin agar, actinomycete agar; and a low incubation temperature $\left(8-12^{\circ} \mathrm{C}\right)$ were used $[1,2]$.

Initially and up until 1995, cave microbiomes were identified based on their cellular morphology using microscopy and staining techniques [2]. The implementation of molecular techniques have overcome the problem of identification of these microbes at the genus and species level. Several cave microbial diversity studies included denaturing gradient gel electrophoresis finger printing and 16S rRNA phylogenetic analysis. For instance, a study by Vlikonja et al. in 2014 [3] from a Slovakian Karstic cave adopted a 16S rRNA gene profiling showing that Streptomyces (25\%), Micrococcus (16\%) and Rhodococcus (10\%) were major constituents of the population, followed by Pseudomonas (9\%), Agrobacterium (8\%), Lysobacter (6\%), while Paenibacillus (5\%) were present as minor members. The cave microbiome studies have drawn considerable interest in finding new antimicrobials from the microorganisms that live in these extreme habitats $[5,13]$. These environments are good habitats for exploration and research, as they potentially contain unknown/less studied bacteria and have not been previously explored for new drugs [2].

Here, we report on the cultivation-based bacterial diversity of Iron Curtain Cave, which has never been studied before. Media plates were swabbed with wall samples from each site in the cave and incubated in situ with lids closed for nine months. The isolates were identified using molecular biology tools based on $16 \mathrm{~S}$ rRNA gene profiling techniques and the molecular phylogenetic analysis. Moreover, the bacterial isolates were screened for their antimicrobial properties against multidrug-resistant bacteria. Our study demonstrated that the investigated cave not only housed less studied/potentially new bacterial taxa, it is also an important resource for the discovery of bioactive compounds.

\section{Materials and Methods}

\subsection{Cave Description}

The Iron Curtain Cave is located near Chilliwack, British Columbia on the north side of Chipmunk Ridge (Supplementary Figure S1). It is a pristine carbonate cave and was discovered by Rob Wall in 1993. The cave's survey was performed and the map was chiefly drawn by Trevor Moelaert in April 1999 (Figure 1). The cave has a unique environment with high iron content sediment and limestone structures throughout. While sediment contains iron that gives it a unique reddish coloration (Figure 2E), it also has a clay consistency that indicates higher levels of moisture. Notably, there are six pools of water present from the entrance and throughout the cave (Figure 1), making the environment within the cave humid. The temperature ranges between $4-12{ }^{\circ} \mathrm{C}$ depending on the time of year. The cave is decorated in different types of speleothem structures formed by secondary mineral deposits from dripping water within the cave. The three main types of speleothems present in the cave are soda straws: long, hollow, calcium carbonate cylinders (Figure 2A,C), bacon: large, wavy, calcium carbonate structures (Figure 2B,D) and popcorn structures present in the "ancient room" (Figure 2G). The main decoration in the Iron Curtain Cave is the large curtain made of calcium carbonate (Figure 2D), which is about $10 \mathrm{ft}$ long and hangs about $30 \mathrm{ft}$ above a deep pool of water. The cave has been exposed to a limited number of people as it is gated and locked, and any access to it needs prior permission from the 
cave custodian, Rob Wall. The limited access to the cave are constrained to a specific path to preserve the features and habitat of the cave.

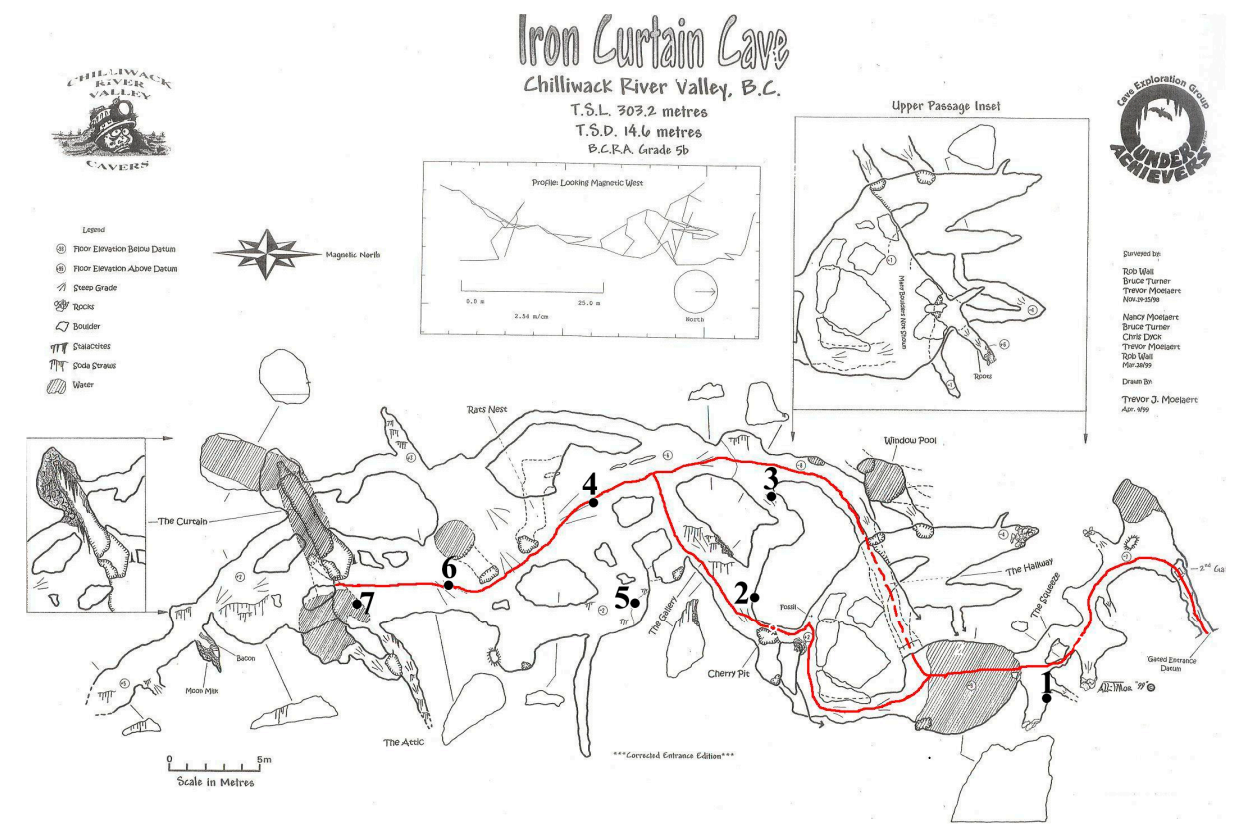

Figure 1. Map of Iron Curtain Cave in Chilliwack B.C. The numerals denote the locations of sampling points where media plates were left for nine months. \#1 = Connection Room; near Squeeze dig around and Looking Pool, \#2 = Upper section of The Gallery, near the climb to the Breakdown room, \#3 = Entrance to side passage across from the Chocolate waterfall, \#4 = Sitting area just beyond Lollipop Passage, \#5 = Octopus Room, \#6 = Mid passage to the Curtain, just past the Wishing Well, \#7 = Chandelier Pit just below The Attic.

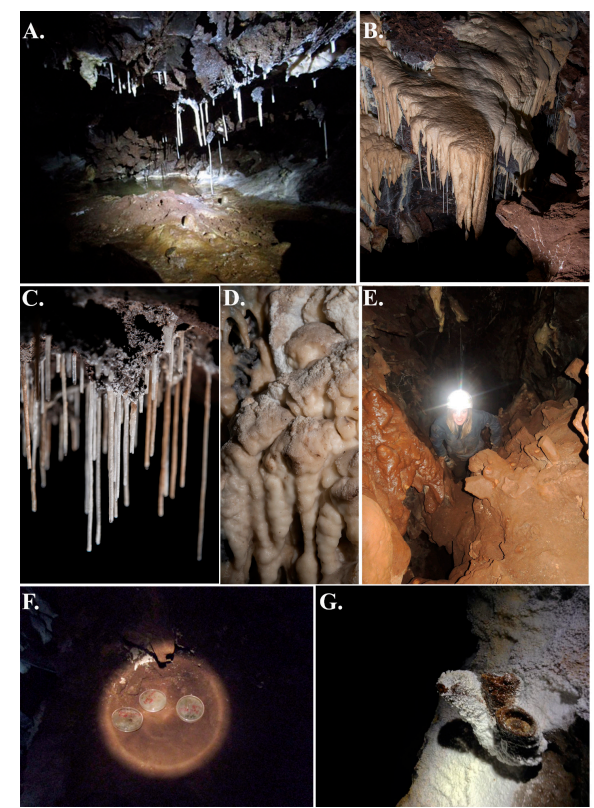

Figure 2. Iron Curtain Cave, Chilliwack, British Columbia, Canada. (A) Site \#4: The Octopus Room; (B,C) Site \#7: with two types of speleothem common to the cave; soda straws and bacon; (D) The Curtain made of calcium carbonate; (E) Soil sediment containing iron as well as some more geographical features unique to the cave; $(F)$ The media plates are exposed for nine months in the cave; (G) The popcorn structures. 


\subsection{Sample Collection and Bacterial Isolation in the Cave}

Seven different sampling points (1-7) were chosen arbitrarily in the cave in order to compare the microbiome diversities (Figure 1). At each site, the swabs of wall samples were inoculated on to the R2A (Teknova, Hollister, CA, USA) and Difco ${ }^{\mathrm{TM}}$ Actinomycete Isolation agar media (Thermo Fisher Scientific Inc., Waltham, MA, USA). These plates were then left with lids closed at these seven different locations in the cave (Figure 1) to mimic the original incubation cave temperature. The incubation temperature during these nine months ranged from $4-8{ }^{\circ} \mathrm{C}$. After nine months from the day of inoculation, these plates were collected from the cave. Plates were transported to the laboratory aseptically for bacterial isolation.

The bacterial isolates from original media plates were cultivated on four types of culture media in order to obtain the best growth medium for each of these isolates: R2A, Actinomyces HiVeg $^{\text {TM }}$ (AHV) broth medium (HiMedia Laboratories Pvt. Ltd., Nashik, India), Hickey-Tresner (HT) (Yeast extract 0.1\%, Beef extract 0.1\%, N-Z Amine 0.2\%, Dextrin 1\%, pH 7.3) [5] and V8 original medium $(200 \mathrm{~mL} / \mathrm{L} ; v / v)$ (Campbell Company, Toronto, ON, Canada) $-\mathrm{CaCO}_{3}(3 \mathrm{~g} / \mathrm{L} ; w / v)$ (Thermo Fisher Scientific Inc., Waltham, MA, USA). Morphologically distinguishable colonies obtained from the exposed plates were streaked and incubated at $8{ }^{\circ} \mathrm{C}$, for a period of $4-8$ weeks, to obtain pure culture. The low incubation temperature was employed to mimic the cave temperature.

The pure culture obtained for each of the bacterial isolates were further inoculated in $3 \mathrm{~mL}$ volume of its respective (original plate) broth media (R2A, AHV, HT) and incubated for a period of 4-6 weeks at $8{ }^{\circ} \mathrm{C}, 15^{\circ} \mathrm{C}$ and $25^{\circ} \mathrm{C}$ for bacterial DNA extraction and antimicrobial activities assay. Three temperature conditions $\left(8^{\circ} \mathrm{C}, 15^{\circ} \mathrm{C}, 25^{\circ} \mathrm{C}\right)$ were employed in order to observe the best growth environments for these bacterial isolates and for their bioactive compound production.

\subsection{Molecular Phylogeny}

\subsubsection{Genomic DNA Extraction and Sequencing}

The broth culture of the bacterial isolates that exhibited maximum growth at the tested temperatures were used for genomic DNA extraction. The DNA extraction was performed as per the protocol followed in a previous study [14], with minor modifications at the cell lysis step. Along with the Proteinase $\mathrm{K}$ and Sodium dodecyl sulfate, lysozyme $(10 \mathrm{mg} / \mathrm{mL})$ was also added, followed by an incubation at $37^{\circ} \mathrm{C}$ for $60 \mathrm{~min}$. Following the extraction, the isolated genomic DNA was subject to polymerized chain reaction amplification of the $16 \mathrm{~S}$ rRNA gene using 27F (5'-AGAGTTTGATCMTGGCTCAG-3') and 1492R (5'-TACGGYTACCTTGTTACGACTT-3') primers [5] in a MyCycler ${ }^{\mathrm{TM}}$ Thermalcycler (BIO-RAD, Mississauga, ON, Canada). A $50 \mu \mathrm{L}$ PCR reaction mixture contained 100-200 ng of template DNA, $0.25 \mu \mathrm{M}$ of each the primers, $1 \mu \mathrm{M}$ deoxynucleotides, $1 \mathrm{mM} \mathrm{MgCl}_{2}$, and $1 \mathrm{U}$ of ExTaq ${ }^{\mathrm{TM}}$ Polyemarase (TakaRa Bio Inc., Olsu, Shiga, Japan) in ExTaq ${ }^{\mathrm{TM}}$ buffer (1X). The thermal cycling parameters were set with an initial denaturation at $94{ }^{\circ} \mathrm{C}$ for $2 \mathrm{~min}$ $30 \mathrm{~s}$ followed by 40 cycles of denaturation at $94{ }^{\circ} \mathrm{C}$ for $30 \mathrm{~s}$, annealing at $54{ }^{\circ} \mathrm{C}$ for $30 \mathrm{~s}$ and extension at $72{ }^{\circ} \mathrm{C}$ for $40 \mathrm{~s}$. The final extension was performed at $72{ }^{\circ} \mathrm{C}$ for $10 \mathrm{~min}$. The PCR products were further resolved on an agarose gel $(0.8 \%)$ containing ethidium bromide to confirm the DNA band profile of the bacterial isolates. The unpurified PCR products were sent for sequencing to Macrogen, Seoul, South Korea. The DNA sequences obtained were analyzed using the BLAST (Basic Local Alignment Search Tool) algorithm with the available sequences in the GenBank at National Center for Biotechnology Information (NCBI) http:/ / www.ncbi.nih.nlm.nih.gov/genebank/index.html [15]. 16S rRNA gene sequences were identified with the $>98 \%$ identity and $>80 \%$ coverage to the closest homologue in the GenBank. GenBank accession numbers are given in Supplementary Table S1.

\subsubsection{Sequence Alignment and Phylogenetic Analysis}

Evolutionary analyses were conducted in MEGA6 [16]. The evolutionary history was inferred using the neighbor-joining method [17]. The optimal tree with the sum of branch length $=2.58482960$ is 
shown. The percentage of replicate trees in which the associated taxa clustered together in the bootstrap test (1000 replicates) are shown next to the branches [18]. The tree is drawn to scale, with branch lengths in the same units as those of the evolutionary distances used to infer the phylogenetic tree. The evolutionary distances were computed using the maximum composite likelihood method [19], and are in the units of the number of base substitutions per site. The analysis involved 65 nucleotide sequences. All positions containing gaps and missing data were eliminated. There were a total of 744 positions in the final dataset.

\subsection{Antimicrobial Activities Screening}

The cave bacterial isolates were tested for their antimicrobial activities against the regular non-resistant and multidrug resistant (MDR) bacterial and normal yeast strains. The regular non-resistant Escherichia coli and Staphylococcus aureus were chosen, while MDR strains were E. coli (New Delhi strain)15-318, E. coli (NDM type carbapenemase)15-102, E. coli (oxa48 type carbapenemase)15-124 and methicillin-resistant S. aureus (MRSA)-43300. The normal bacterial strains of Pseudomonas aeruginosa, Serratia marcescens and the yeast strain Candida albicans were also included as test microbes in this study. The MDR E. coli 15-102, 15-124, 15-318 strains were provided by LifeLabs, Canada while non-resistant E. coli and Candida albicans were available at the Thompson Rivers University culture collections. S. marcescens and S. aureus MRSA-43300 were kindly donated by Dr. Julian Davies, University of British Columbia, Canada, and Royal Inland Hospital, Canada. All the test bacteria and yeast isolated colonies were inoculated in $3 \mathrm{~mL}$ nutrient broth (Criterion ${ }^{\mathrm{TM}}$ Dehydrated Culture Media, Hardy Diagnostics, CA, USA) and potato dextrose broth (Hi Media Laboratories Pvt. Ltd., Mumbai, India), respectively, with shaking at $37^{\circ} \mathrm{C}$ and $25^{\circ} \mathrm{C}$ on test tube rotator overnight.

The antimicrobial activities screening was performed by seeded agar method on nutrient agar, and potato dextrose agar for bacteria and yeast, respectively. All the test microorganisms were inoculated at an concentration of $10^{6} \mathrm{cfu} / \mathrm{mL}$ in $250 \mathrm{~mL}$ of the media, mixed gently by shaking and poured in Nunc ${ }^{\circledR}$ Bioassay Dish $(245 \mathrm{~mm} \times 245 \mathrm{~mm} \times 25 \mathrm{~mm}$ ) (Cole-Parmer Scientific Experts, Montreal, QC, Canada). Five microliters of the previously grown broth culture of cave bacterial isolates were spotted on the solidified agar plate. Peroxigard (1.5\% v/v) (Bayer, Toronto, ON, Canada), bleach $10 \%(w / v)$ (London Drugs, Richmond, BC, Canada) and ampicillin disks $(10 \mu \mathrm{g})$ (In Vitro Diagnostic (IND Diagnostic Inc.), Delta, BC, Canada) were used as positive controls whereas uninoculated R2A broth medium was the negative control. All the plates were incubated at $15^{\circ} \mathrm{C}$ in the upright position till the well-developed consistent lawn of the test microbe was observed. The antimicrobial activities was determined as the zone of inhibition around each bacterial colony. The diameter of the zone of the inhibition was measured manually with electronic Vernier calliper (Guangxi China, Mainland).

In order to examine which culture medium supports the antimicrobial activities maximally, the positive candidates that exhibited antimicrobial activities after screening were further grown in four different fermentation media: R2A, V8, HT, and Actinomyces HiVeg ${ }^{\mathrm{TM}}$ broth, incubated at $8{ }^{\circ} \mathrm{C}$ and re-spotted on the agar seeded test microorganisms media plate. The plates were incubated at $15{ }^{\circ} \mathrm{C}$ to observe the antimicrobial activities.

\subsection{Scanning Electron Microscopy (SEM) of Bacterial Isolates with Antimicrobial Properties}

The bacterial samples were grown on the agar media plate, and one colony from each plate were excised. The excised samples were osmium fumed in an airtight container with $4 \% \mathrm{OsO}_{4}$ (aq) mixed with an equal volume of acetone for approximately $30 \mathrm{~min}$. Samples were post-fixed in $8 \%$ glutaraldehyde $+1 \%$ tannic acid, under vacuum, using a microwave protocol (Pelco 3431 Laboratory Microwave, Redding, CA, USA). Following post-fixation, the samples were washed and taken through a staged ethanol dehydration, accelerated by microwave. The samples were kept at $70 \%$ ethanol overnight at $4{ }^{\circ} \mathrm{C}$, and the staged dehydration was completed the following day. Critical point drying was accomplished using a Tousimis Auto-Sam Dri $815 \mathrm{~B}$ with one $10 \mathrm{~min}$ purge and one $5 \mathrm{~min}$ purge separated with a standing time in liquid carbon dioxide for $30 \mathrm{~min}$, followed by an overnight stasis and one last $5 \mathrm{~min}$ purge before heating the 
sample to the critical point. The samples were mounted to aluminum scanning electron microscopy (SEM) stubs using double-sided, carbon conductive tabs and sputter coated with $8 \mathrm{~nm}$ PtPd (Cressington 208HR) and imaged on either Hitachi S 2600 VP-SEM or Hitachi S4700 cold-FESEM.

\section{Results}

The present study elucidated the preliminary cultivable bacterial community profile of the Iron Curtain Cave, Chilliwack, BC, Canada employing the cultivation based 16S rRNA profiling approach. Furthermore, the study also evaluated the antimicrobial properties of the bacterial isolates against the microbial drug resistant strains and pathogens.

\subsection{Sampling Location in the Cave}

The distances of each of the seven sites from the entrance of the cave were measured and given in the Figure 3.

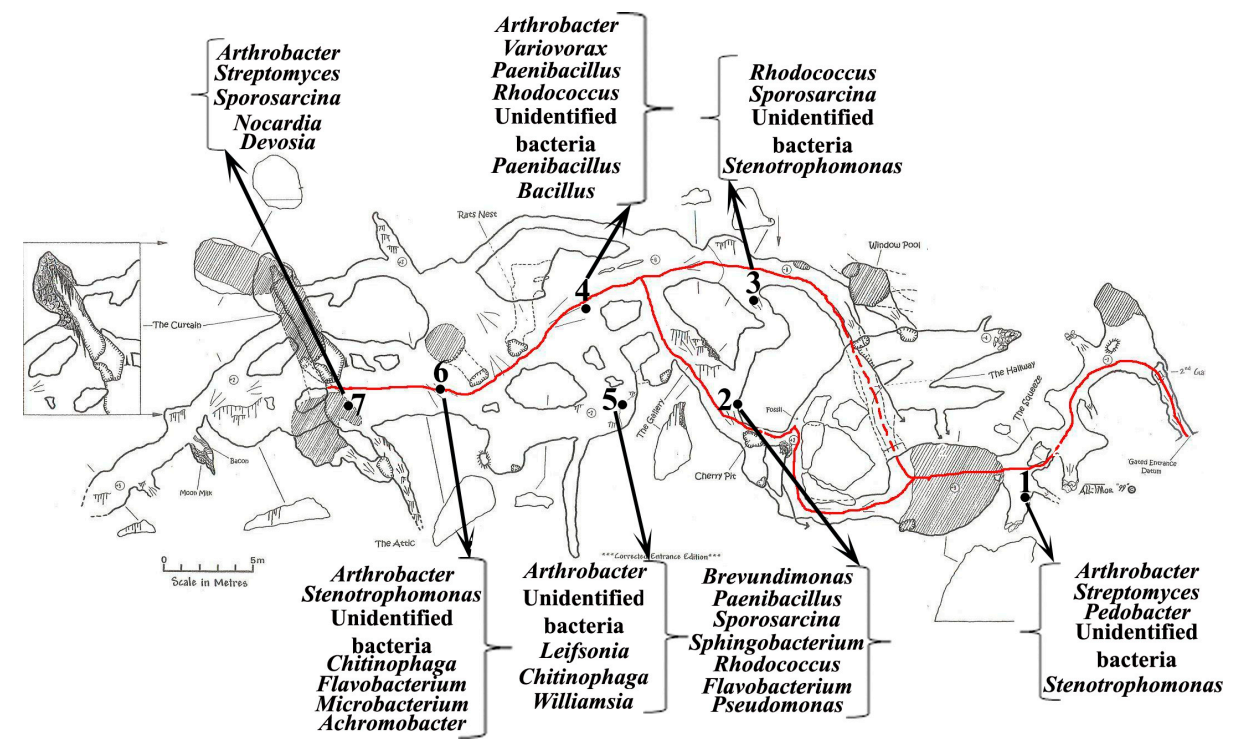

Figure 3. Distribution of bacterial isolates at different sampling points in Iron Curtain Cave, Chilliwack, BC, Canada.

\subsection{Bacterial Community Composition}

The bacterial isolates were subcultured on their respective culture media, $\mathrm{R} 2 \mathrm{~A}$, Actinomyces HiVeg ${ }^{\mathrm{TM}}$ broth, HT, and V8 media both at $8{ }^{\circ} \mathrm{C}$ and $15^{\circ} \mathrm{C}$, while no growth were observed at $25^{\circ} \mathrm{C}$ for most of the bacterial isolates.

Sixty five bacterial isolates were cultivated, followed by genomic DNA extraction, which were further subjected for the $16 \mathrm{~S}$ rRNA gene amplification. The PCR product revealed amplicons ranging from 1300-1500 bp. The nucleotide sequencing of these amplicons categorized bacterial isolates into four major phyla, including Actinobacteria, Proteobacteria, Firmicutes and Bacteroidetes (Figure 4). Further investigations revealed genera of Arthrobacter (21.53\%) as the major genus, followed by Stenotrophomonas (9.23\%), Sporosarcina (9.23\%), Streptomyces (6.15\%), and Brevundimonas (4.61\%). Species of Rhodococcus, Bacillus, Paenosporosarcina, Paenibacillus, Williamsia, Leifsonia, Nocardia, Devosia and Flavobacterium were identified as 3.07\%, while the members of genera Pedobacter, Sphingobacterium, Chitinophaga, Pseudomonas, Microbacterium, Achromobacter and Variovorax accounted for the minor (1.53\%) population of the cultivable diversity. Crocebacterium exhibited $2.8 \%$ of the bacterial population identified, and $12.30 \%$ were identified as unidentified bacterium. Notably, $26.15 \%$ of the bacterial isolates exhibited $\leq 98 \%$ when compared with available with $16 \mathrm{~S}$ rRNA sequences in GenBank (Supplementary Tables S1 and S2). 

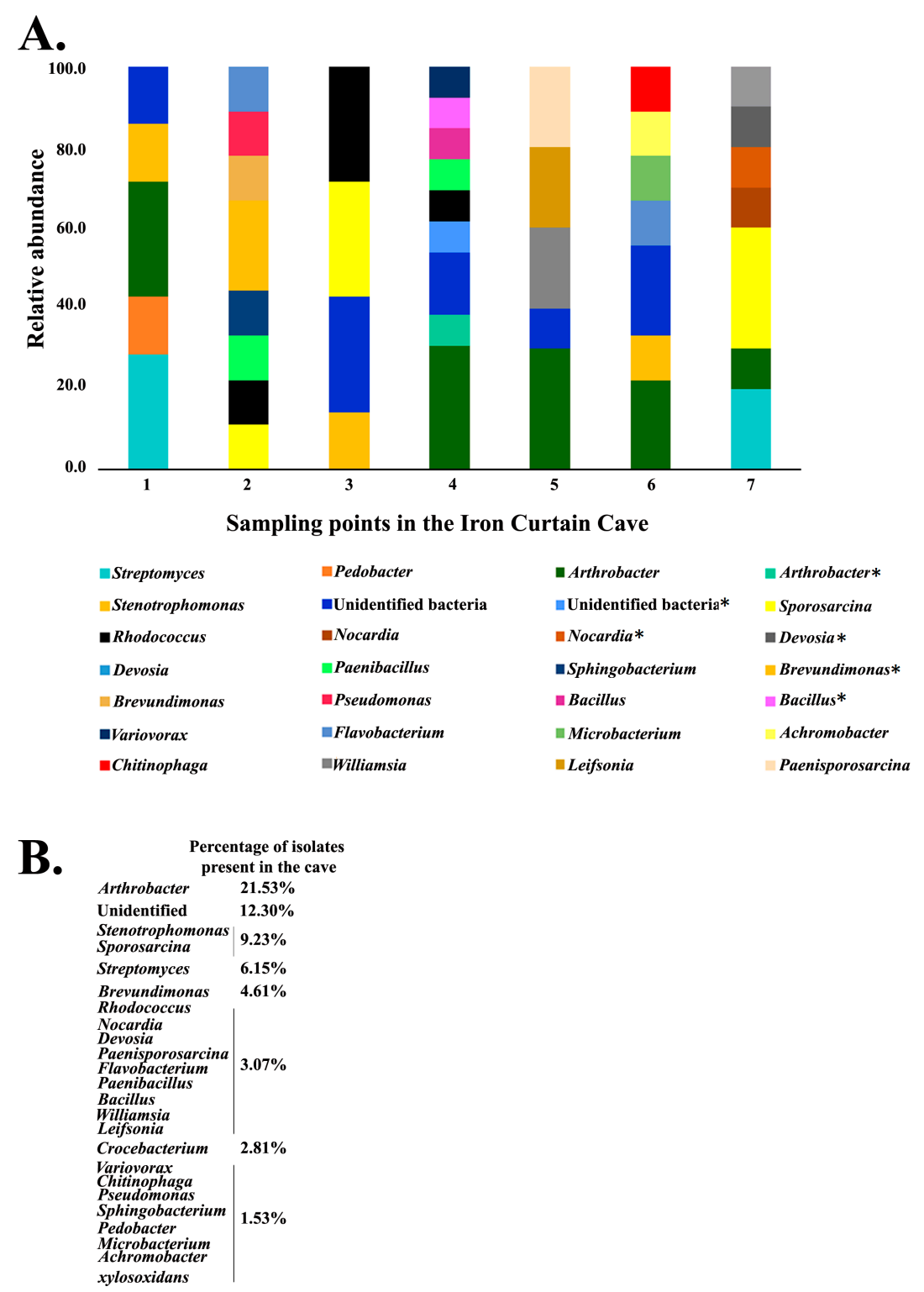

Figure 4. (A) Taxonomical distribution of the bacterial isolates from Iron Curtain Cave by sampling sites. The vertical rectangular stalked columns represent the relative bacterial abundance. The asterisk ${ }^{*}$ ) denotes the percentage of the bacteria that are not assigned with the gene accession numbers.

(B) Percentage of total isolates from all sampling sites.

The Arthrobacter spp. and the unidentified bacterium were widely distributed in most of the sampling points, including points numbered 1, 4, 5, 6, 7 and 1, 3, 4, 5, 6 respectively (Figure 4A,B). The species Stenotrophomonas, Sporosarcina and Rhodococcus were identified only at three points, while Streptomyces, Paenibacillus and Flavobacterium were found at two points only. The rest of the bacteria identified were minimally distributed and found at one spot only (Figure 4A,B).

\subsection{Phylogenetic Analysis}

The evolutionary relatedness of these bacterial isolates depicted in the dendrogram demonstrated Actinobacteria $(44.61 \%)$ were the major phylum, followed by Proteobacteria $(27.69 \%)$ and Firmicutes $(20 \%)$, and the least common phylum were Bacteroidetes (7.69\%). Proteobacteria and Firmicutes were identified as $27.69 \%$ and $20 \%$ respectively. Among the Proteobacteria, $55.55 \%$ were recognized in the class of Gammaproteobacteria, $27.77 \%$ as Alphaproteobacteria and $16.66 \%$ as Betaproteobacteria. 
The unknown bacterial isolates fall in clades of Arthrobacter spp. (Phylum Actinobacteria), Stenotrophomonas spp. (Phylum: Gammaproteobacteria) and Paenibacillus spp. (Phylum Firmicutes) (Figure 5). Notably, both the antimicrobial bacterial isolates (ICC1 and ICC4) may be identified under the phylum Actinobacteria; however, with ICC1's sequence having low similarity (73\%) to the Streptomyces nojiriensis (Table S2), it is hence referred to as an unidentified bacterium.

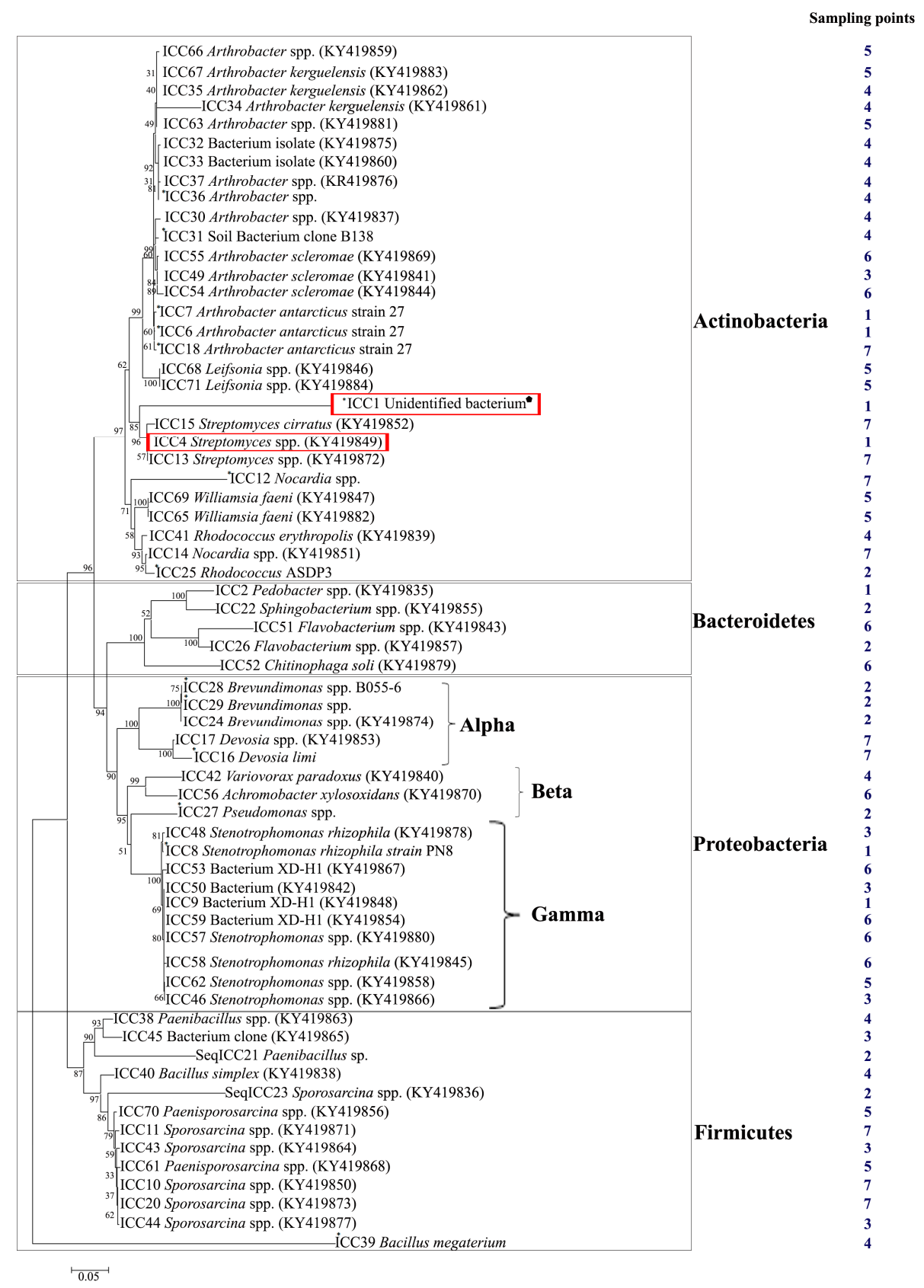

Figure 5. Evolutionary relationships of taxa. The $16 \mathrm{~S}$ rRNA gene sequences obtained from the NCBI gene database were aligned by MUSCLE with default parameters. The phylogenetic tree was constructed using MEGA6 by neighbor-joining method, with a bootstrap test of 1000 replicates. The asterisk $\left(^{*}\right)$ denotes the sequences that were not assigned with a GenBank accession number. The red boxes represents the bacterial isolates that exhibited antimicrobial properties. The polygonal (-) represents the ICC1 having an identity of $73 \%$ to Streptomyces nojiriensis. 


\subsection{Antimicrobial Activities of the Cave Bacteria}

Two bacterial isolates exhibited antimicrobial activities. Surprisingly, these activities were only observed when the bacteria were grown in V8 and HT media at $8{ }^{\circ} \mathrm{C}$. While the ICC4 (closest relative: Streptomyces spp., $99 \%$ identity) isolate exhibited a wide range of antimicrobial activities against regular non-resistant strains of E. coli, S. aureus and MDR strains of E. coli 15-318, E. coli 15-102, E. coli 15-124 and P. aeruginosa, the ICC1 showed activity against E. coli 15-102 and E. coli 15-124 only (Table 1). ICC1 was not deposited to GenBank (Supplementary Table S2) because of its low identity (73\%), although it showed $95 \%$ coverage. However, the closest relative was identified to be Streptomyces nojiriensis.

Table 1. Antimicrobial activities. ICC4 (Closest relative: Streptomyces spp.) and ICC1 (Unidentified bacterium). The numerical in the boxes indicated the diameter of zones of inhibition in $\mathrm{mm}$. The antimicrobial activities were observed at $8{ }^{\circ} \mathrm{C}$. The symbol (-) denotes 'no antimicrobial activities'. No antimicrobial activity was observed in all cave isolates tested against Serratia marcescens or Candida albicans.

\begin{tabular}{|c|c|c|c|c|c|c|c|c|}
\hline \multirow{2}{*}{$\begin{array}{l}\text { Bacterial } \\
\text { Isolates }\end{array}$} & \multirow{2}{*}{$\begin{array}{l}\text { Growth } \\
\text { Media }\end{array}$} & \multicolumn{7}{|c|}{ Test Microorganisms } \\
\hline & & E. coli & $\begin{array}{l}\text { E. coli } \\
15-318\end{array}$ & $\begin{array}{l}\text { E. coli } \\
15-102\end{array}$ & $\begin{array}{l}\text { E. coli } \\
15-124\end{array}$ & $\begin{array}{c}\text { Staphylococcus } \\
\text { aureus }\end{array}$ & MRSA-43300 & $\begin{array}{c}\text { Pseudomonas } \\
\text { aeruginosa }\end{array}$ \\
\hline \multirow{4}{*}{ ICC1 } & V8 & - & - & - & - & - & - & - \\
\hline & R2A & - & - & 14 & 8 & - & - & - \\
\hline & AHV & - & - & - & - & - & - & - \\
\hline & HT & - & - & - & - & - & - & - \\
\hline \multirow{4}{*}{ ICC4 } & V8 & 13 & 17 & 21 & 8 & 13 & - & 7 \\
\hline & R2A & - & - & - & - & - & - & - \\
\hline & AHV & - & - & - & - & - & - & - \\
\hline & HT & 24 & - & - & - & 12 & - & - \\
\hline
\end{tabular}

\subsection{Scanning Electron Micrographs}

The SEM images of the ICC1 and ICC4 isolates revealed the presence of possible actinobacterial-like structures. To confirm this observation, 16S rRNA sequencing was performed to obtain the isolates' identity. Morphological characteristics observed for these two isolates were found to coincide with Streptomyces's common characters. These two isolates were rod-shaped in long interwoven filaments, with a diameter of about 0.3 to $0.5 \mu \mathrm{m}$ (Figure 6).
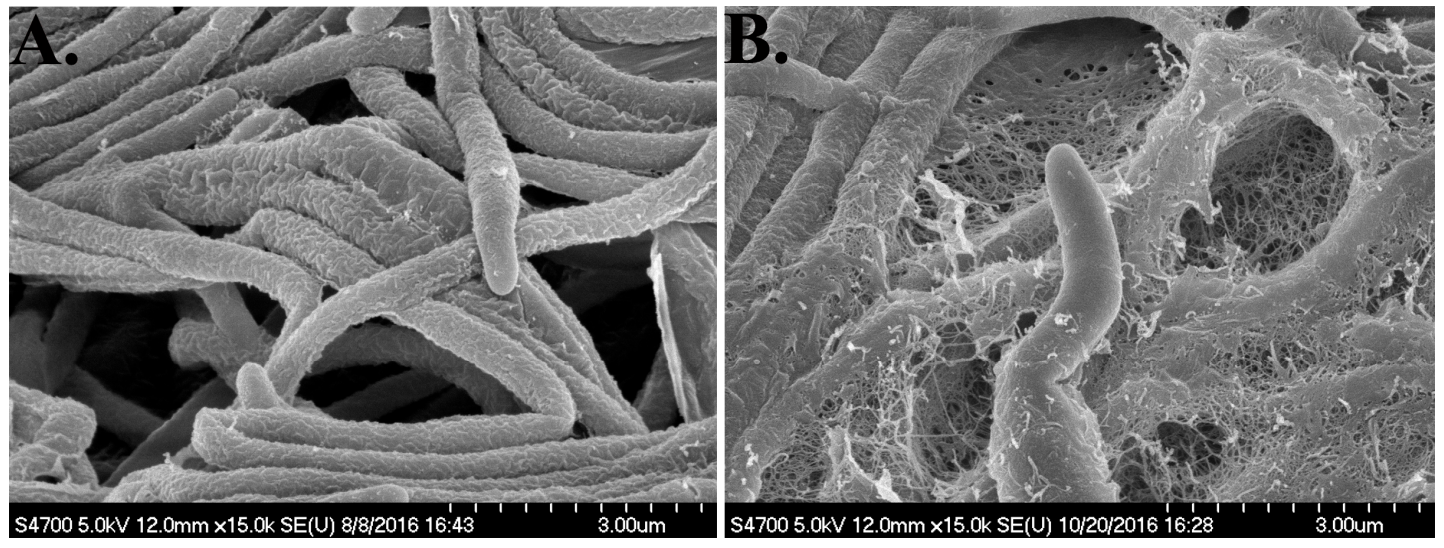

Figure 6. SEM images of actinobacterial-like structures from Iron Curtain Cave samples. (A) ICC1: Dense mass of rod-shaped and interwoven filaments with irregular rugose surface, Scale bars, $5 \mu \mathrm{m}$; (B) ICC4: Mass of hyphae with smoother surface, Scale bars, $3 \mu \mathrm{m}$. 


\section{Discussion}

Our study of cultivation-/PCR-based microbial diversities, and evaluation of their antimicrobial properties, were performed for the first time from the Iron Curtain Cave, Chilliwack, Canada. The earlier microbial ecology studies conducted on these caves involved identifying the presence of bacteria on soda straw samples through isolation followed by SEM [20]. However, those studies essentially lacked the purification, molecular identification, and more importantly, antimicrobial activities screening of the purified bacterial isolates. Our investigations, though preliminary, encompassed culturable in situ microbial diversity and their potential in antimicrobial activity production. The study detected four phyla of the bacterial population with Actinobacteria as the major phylum, followed by Proteobacteria, Firmicutes and Bacteroidetes (Figure 5).

The dominance of Actinobacteria (44.61\%) in our study is in accordance with previous microbial ecology studies of limestone caves where Actinobacteria was identified as the predominant bacterial population [21,22]. Our study showed that among the Actinobacterial phylum, Arthrobacter spp. occupied the vast majority $(48.27 \%)$, which could not be identified in earlier studies $[13,23]$. About $10.10 \%$ of the Actinobacterial phylum contained unidentified bacterium that clustered together with Arthrobacter (Figure 5). Our findings suggested Streptomyces spp. as the second largest class $(13.79 \%)$ in the Actinobacterial phylum. However, most of the previous microbial diversity studies both from Karstic and volcanic caves identified Streptomyces as the major bacterial class [22,24,25]. Rhodococcus spp. (6.89\%) and Nocardia spp. (3.44\%) were also recognized in our study. A study from Riquelme et al. 2017 has reported the presence of these genera in the Canadian and Azorean volcanic cave [24]. However, a study from Jurado et al. 2010 designated both Rhodococcus spp. and Nocardia spp. as opportunistic and possibly pathogenic cave bacteria [26]. Furthermore, our investigation has demonstrated the presence of Leifsonia spp. (6.89\%) and Williamsia spp. (6.89\%), which had never been reported in any previous studies of a cave environment. However, studies have reported Leifsonia spp. from different environments, such as teak rhizosphere soil [27], Japanese lichen [28] and ginseng root [29]. Similarly, Williamsia was also demonstrated from an oil-contaminated soil [30] and human blood [31].

Proteobacteria are the second most abundant phylum observed in our investigations. Earlier, a similar study from Blowing Spring Cave (Lauderdale County, Alabama) reported Gammaproteobacteria (23\%) as the most prevalent group, followed by Alphaproteobacteria (19\%) and Betaproteobacteria (1\%) [32]. Among the Gammaproteobacteria, Stenotrophomonas spp. was only observed in the phylum. Four unidentified bacteria were also observed to be clustered in the same clade of Stenotrophomonas spp. (Figure 5). One of the earlier studies has isolated Stenotrophomonas from the Karstic Herrenberg Cave, Germany and identified it to be involved in calcite biomineralization [23]. Among the Alphaproteobacteria phyla, our study has observed Brevundimonas spp. as the major class (60\%) along with Devosia spp. (40\%). In correlation to our findings, a study by Busquets et al. in 2014 reported two strains and two species of Brevundimonas from the alkaline waters of the cave pools at the Cova des Pas de Vallgornera (Mallorca, Western Mediterranean, Spain) [33], while another study by Shabarova et al. in 2010 reported Devosia spp. from the water sample collected from three pools of the Bärenschacht cave system (Switzerland) [34].

Among the Betaproteobacteria phylum, three different species of bacteria were identified: Variovorax, Achromobacter and Pseudomonas (1:1:1). The presence of Variovorax in our findings could be correlated to an earlier microbial diversities study from Lechuguilla and Spider Caves (Carlsbad Caverns National Park, in Eddy County in Southeastern New Mexico, USA), where two bacterial clones identified as the nearest homologue to Variovorax [35]. Numerous studies reported Pseudomonas as the prevalent species in the cave environment. For instance, eight strains and five species of Pseudomonas were reported to play roles in the regulation of the biogeochemistry from the Majorcan Caves [33]. Similarly, another bacterial diversity study from the bacterial biofilms explored from five caves from the Meghalaya in India, and identified Pseudomonas spp. as the major genus [36]. We found the presence of Achromobacter spp., although other studies have rarely identified 
it. For instance, a previous study on the Lascaux Cave (Vezere Valley, Montignac, France) detected $3.6 \%$ of bacterial clones as Achromobacter xylosoxidans [37].

Firmicutes were the third abundant phylum detected in our study. Although most of the other studies identified Sporosarcina as rare Firmicutes in the cave environment [38], our study identified $46.15 \%$ of Sporosarcina. In agreement with our study, a study by Kim et al. [38] has revealed two bacterial isolates, Sporosarcina globispora and Sporosarcina spp., from limestone cave soil samples that play crucial roles in calcite precipitation in the cave soil. Bacillus $(15.38 \%)$ has also been observed as one of the genus in our study. An earlier study, both by cultivation-dependent and -independent approaches, identified Bacillus as a common microbe [39]. Surprisingly, both of the Bacillus spp. (ICC40 and ICC39) identified in our study have been found to be apart from each other on the phylogenetic tree (Figure 5). However, a study reported that the Bacillus species is an incoherent taxon that lacks a common evolutionary history [40]. Our study has identified two isolates of Paenibacillus spp. (occupying $15.38 \%$ of the total Firmicutes population). Furthermore, one of the unidentified bacteria also falls in the clade of the Paenibacillus spp. (Figure 5). Previously, the Paenibacillus cavernae spp. was reported to be isolated from soil in one of the natural caves in Jeju, Republic of Korea [41]. Moreover, Paenibacillus spp. was well known to possess antibiotic resistome on their genome. For instance, Pawlowski et al. [42] has identified a Paenibacillus spp. LC231 from Lechuguilla Cave and after a detailed whole-genome sequencing, functional genomics, and biochemical analysis, it has exhibited resistance to a wide array of antibiotics. Interestingly, $15.38 \%$ of Paenisporosarcina spp. were detected in our study; this species was never been reported before from any caves studied. However, studies have showed the identification of this genus from other habitats, such as glacier water (Paenisporosarcina indica sp. nov.) [43] and a landfill site (Paenisporosarcina quisquiliarum sp. nov.) [44].

Bacteroidetes were the least abundant phylum identified in the Iron Curtain Cave. The Bacteroidetes contained the genera that exhibited close homology to Pedobacter spp., Sphingobacterium spp., Flavobacterium spp. and Chitinophaga spp. (Figure 5). In relation to our study, Flavobacterium spp. was previously reported in abundance in Ferromanganese deposits from the caves of the Upper Tennessee River Basin, along with other bacteria indicating that this bacterium contributed Mn (II) oxidation [45]. The presence of this bacterium in the Iron Curtain Cave indicates that it might potentially participate in the iron oxidation of the cave, and impart a reddish coloration to the soil sediment (Figure 2E). Similarly, in 2013 Engel et al. identified both Sphingobacterium and Flavobacterium in the calcium carbonate speleothem samples from two Italian caves and both clustered in the same clade [46]. Chitinophaga spp. was also observed in our study, which was never reported before from a cave. However, other studies reported Chitinophaga spp. from other sources, such as C. qingshengii sp. nov. isolated from weathered rocks [47] and C. ginsengihumi sp. nov. from the soil of ginseng rhizosphere [48]. In our study, the microbial diversity study specifically revealed that the sampling points differed in their microbial content, although overlap of the microbial populations was observed between many of the sampling points (Figures 3 and 4). This varied microbial content observed among the seven points is an important revelation implying that each of the sampling point could be a potential microhabitat within a single cave environment. However, the bacterial taxonomic profile did not reveal a comprehensive pattern identified at each of the sampling points, and therefore further studies needed to be conducted.

The antimicrobial activity screening of the identified bacterial isolates (ICC1 and ICC4) detected two homologues of Streptomyces spp. that possess antagonistic properties against regular and MDR bacterial strains of E. coli. Although the ICC1 has exhibited a very low homology of 73\% to Streptomyces spp., SEM images of the both the isolates displayed Actinobacterial-like structures (Figure 6). Both SEM images showed typical aerial hyphae that are densely packed without spores being observed. ICC1 showed interwoven filaments with an irregular rugose surface, while ICC4's hyphae was observed with a rather smoother surface. The antimicrobial activities of these bacteria could be correlated to a previous study on Turkish Karstic caves, where Streptomyces spp. strain number 1492 (Actinomycetes bacteria) displayed antagonism against S. aureus (MRSA), vancomycin resistant Enterobacter faecium 
(VRE), and Acinetobacter baumannii [49]. A similar study from the Helmcken Cave in Wells Gray Provincial Park, BC (volcanic caves) identified 400 bacterial isolates, where a preliminary screening of these bacteria for antimicrobial activities identified $26.50 \%$ against K. pneumoniae, $10.25 \%$ showed inhibitory activity against $M$. luteus, $9.25 \%$ against $M$. smegmatis, $7.5 \%$ against $C$. albicans, $6.25 \%$ P. aeruginosa, $2.25 \%$ against $A$. baumannii, $2 \%$ against $S$. aureus, $1.75 \%$ against $E$. coli and $1 \%$ against ESBL E. coli [5]. In alignment to our findings, a recent review article [1] indicated that cave microbiomes has recently been considered as potential resources for novel drugs and antibiotics. Notably, both ICC1 and ICC4 isolates were from sampling point one in the cave. We intended to use quantitative analysis and comparison of the cultured bacterial diversity among the seven sites to see whether there is any connection between site(s), its microbial habitants, and antimicrobial activity potential. However, we think more detailed studies need to be conducted before we can conclude on such relationships.

Our study has also identified that the antimicrobial activities of ICC1 and ICC4 were fermentation-media specific (Table 1), which was never being elucidated before from the cave environment. However, other studies demonstrated antimicrobial activities of microbial isolates in a fermentation-medium dependent manner. For instance, a study reported that Ellisidothis inquinans L1588-A8 exhibited antifungal activities against Saccharomyces cerevisiae strain EC19 [50]. E. inquinans L1588-A8 antimicrobial activities were only observed when it was incubated in media A and No.2 and not in F1A and MW [50]. However, our study has identified the two bacterial isolates (ICC1 and ICC4) possessing antimicrobial activities, and hinted that the antimicrobial components could be a possible proteinaceous compound (unpublished data). Further investigations, such as whole genome sequencing, functional genomics, biochemical assays, fermentation structure elucidation, active component extraction and mode of action need to be performed in order to fully characterize these antimicrobial activities.

\section{Conclusions}

Our present study is the first report attempting to shed light on microbial diversity and their potential in antimicrobial activity on in situ cultured bacterial diversity. This study is by no means a whole picture of this habitat; however, we believe that this finding can still contribute a small piece of the puzzle of the big picture of cave microbial diversity. Not surprisingly, cultivation-based approaches have certain limitations; nevertheless, our study has documented the Iron Curtain Cave as a rich reservoir for potentially unique metabolites. Therefore, future studies should embark on the metagenomic exploration, which will be a holistic approach for the taxonomical and functional profiling (bioprospecting potential molecules such as enzymes/and of antibiotics of industrial and pharmaceutical relevance) of the Iron Curtain Cave. Additionally, the potential microbial and mineral interactions and the cave population dynamics could also be elucidated.

Supplementary Materials: The following are available online at www.mdpi.com/1424-2818/9/3/36/s1, Figure S1: The area shaded with red lines shows the Chipmunk Ridge. The Iron Curtain Cave is located on the north of this ridge, Table S1: Bacterial isolates identified to their closest homologue, with their GenBank accession number assigned, from different locations in the Iron Curtain Cave, Chilliwack, BC, Table S2: Bacterial isolates that have not been deposited to GenBank hence without accession numbers. These are identified to their closest homologue. The asterisk $\left(^{*}\right)$ denotes the bacteria that show identity below $90 \%$.

Acknowledgments: We are thankful to British Columbia Speleological Federation and Chilliwack River Valley cavers namely Trevor Moelaert, Dayon Traynor, Doug Storozynski, Phil Whitfield, Charly Caproff and Cheeptham's TRU IRFFST Internal Fund. Thanks also go to Ross Holmes for taking the time to assist us with the Chipmonk map. We are also thankful to Julian Davies of UBC for providing us with Serratia marcescens and Wendy Cummer and Michael Kelly of LifeLabs for MDR E. coli strains. We are grateful to Cesareo Saiz-Jimenez of Instituto de Recursos Naturales y Agrobiologia, IRNAS-CSIC, Seville, Spain, and Dipesh Prema of TRU, for their insightful suggestions and comments for this manuscript preparation.

Author Contributions: Naowarat Cheeptham obtained funding, conceived the study and designed the experiment. Soumya Ghosh, Elise Paine, Gabrielle Kam, Tanna Lauriente and Pet-Chompoo Sa-ngarmangkang conducted all the experiments under the close guidance and supervision of Naowarat Cheeptham. Soumya Ghosh analyzed the data and drafted the manuscript. Elise Paine, Rob Wall and Naowarat Cheeptham collected all 
samples from the caves. Derrick Horne performed the SEM of the microbial samples. Naowarat Cheeptham and Soumya Ghosh read and edited the manuscript.

Conflicts of Interest: The authors declare no conflict of interest.

\section{References}

1. Ghosh, S.; Kuisiene, N.; Cheeptham, N. The cave microbiome as a source for drug discovery: Reality or pipe dream? Biochem. Pharmacol. 2016, 134, 18-34. [CrossRef] [PubMed]

2. Cheeptham, N. Advances and challenges in studying cave microbial diversity. In Caves Microbiome: A Novel Resource for Drug Discovery; Cheeptham, N., Ed.; SpringerBriefs in Microbiology: New York, NY, USA; Heidelberg, Germany; Dordrecht, The Netherlands; London, UK, 2013; pp. 1-34.

3. Velikonja, B.H.; Tkavc, R.; Pašić, L. Diversity of cultivable bacteria involved in the formation of macroscopic microbial colonies (cave silver) on the walls of a cave in Slovenia. Int. J. Speleol. 2014, 43, 45-56. [CrossRef]

4. Lavoie, K.H.; Winter, A.S.; Read, K.J.; Hughes, E.M.; Spilde, M.N.; Northup, D.E. Comparison of bacterial communities from lava cave microbial mats to overlying surface soils from lava beds national monument, USA. PLoS ONE 2017, 12, e0169339. [CrossRef] [PubMed]

5. Cheeptham, N.; Sadoway, T.; Rule, D.; Watson, K.; Moote, P.; Soliman, L.C.; Azad, N.; Donkor, K.K.; Horne, D. Cure from the cave: Volcanic cave actinomycetes and their potential in drBug discovery. Int. J. Speleol. 2013, 42, 35-47. [CrossRef]

6. Barton, H.A.; Taylor, M.R.; Pace, N.R. Molecular phylogenetic analysis of a bacterial community in an oligotrophic cave environment. Geomicrobiol. J. 2004, 21, 11-20. [CrossRef]

7. Tebo, B.M.; Davis, R.E.; Anitori, R.P.; Connell, L.B.; Schiffman, P.; Staudigel, H. Microbial communities in dark oligotrophic volcanic ice cave ecosystems of Mt. Erebus, Antarctica. Front. Microbiol. 2015, 6, 179. [CrossRef] [PubMed]

8. Porca, E.; Jurado, V.; Zgur-Bertok, D.; Saiz-Jimenez, C.; Pasic, L. Comparative analysis of yellow microbial communities growing on the walls of geographically distinct caves indicates a common core of microorganisms involved in their formation. FEMS Microbiol. Ecol. 2012, 81, 255-266. [CrossRef] [PubMed]

9. Wu, Y.; Tan, L.; Liu, W.; Wang, B.; Wang, J.; Cai, Y.; Lin, X. Profiling bacterial diversity in a limestone cave of the western loess plateau of China. Front. Microbiol. 2015, 6, 244. [CrossRef] [PubMed]

10. Man, B.; Wang, H.; Xiang, X.; Wang, R.; Yun, Y.; Gong, L. Phylogenetic diversity of culturable fungi in the Heshang Cave, China. Front. Microbiol. 2015, 6, 1158. [CrossRef] [PubMed]

11. Pusz, W.; Ogórek, R.; Knapik, R.; Kozak, B.; Bujak, H. The occurrence of fungi in the recently discovered Jarkowicka Cave in the Karkonosze Mts. (Poland). Geomicrobiol. J. 2015, 32, 59-67. [CrossRef]

12. Ogórek, R.; Lejman, L.; Matkowski, K. Fungi isolated from Niedźwiedzia Cave in Kletno (lower Silesia, Poland). Int. J. Speleol. 2013, 42, 161-166. [CrossRef]

13. Nimaichand, S.; Devi, A.M.; Tamreihao, K.; Ningthoujam, D.S.; Li, W.J. Actinobacterial diversity in limestone deposit sites in Bundung, Manipur (India) and their antimicrobial activities. Front. Microbiol. 2015, 6, 413. [CrossRef] [PubMed]

14. Wilson, K. Genomc DNA extraction using the modified CTAB method. In Current Protocols in Molecular Biology; Ausubel, F.M., Brent, R., Kingstone, R.E., Moore, D.D., Seidman, J.G., Smith, J.A., Struhl, K., Eds.; John Willey and Sons: Hoboken, NJ, USA, 1997; Chapter 2.4.1-2.4.5.

15. Altschul, S.F.; Madden, T.L.; Schaffer, A.A.; Zhang, J.; Zhang, Z.; Miller, W.; Lipman, D.J. Gapped BLAST and PSI-BLAST: A new generation of protein database search programs. Nucleic Acids Res. 1997, 25, 3389-3402. [CrossRef] [PubMed]

16. Tamura, K.; Stecher, G.; Peterson, D.; Filipski, A.; Kumar, S. MEGA6: Molecular evolutionary genetics analysis version 6.0. Mol. Biol. Evol. 2013, 30, 2725-2729. [CrossRef] [PubMed]

17. Saitou, N.; Nei, M. The neighbor-joining method: A new method for reconstructing phylogenetic trees. Mol. Biol. Evol. 1987, 4, 406-425. [PubMed]

18. Felsenstein, J. Confidence limits on phylogenies: An approach using the bootstrap. Evolution 1985, 39, 783-791. [CrossRef] [PubMed]

19. Tamura, K.; Nei, M.; Kumar, S. Prospects for inferring very large phylogenies by using the neighbor-joining method. Proc. Natl. Acad. Sci. USA 2004, 101, 11030-11035. [CrossRef] [PubMed] 
20. Mason, C.; Randhawa, A.; Watson, K.; Friedman, C.R.; Cheeptham, N. Using scanning electron microscopy to study microbial communities in speleothem samples collected from Iron Curtain Cave. J. Exp. Microbiol. Immunol. 2016, 2, 1-7.

21. Ortiz, M.; Neilson, J.W.; Nelson, W.M.; Legatzki, A.; Byrne, A.; Yu, Y.; Wing, R.A.; Soderlund, C.A.; Pryor, B.M.; Pierson, L.S.; et al. Profiling bacterial diversity and taxonomic composition on speleothem surfaces in Kartchner Caverns, AZ. Microb. Ecol. 2013, 65, 371-383. [CrossRef] [PubMed]

22. Riquelme, C.; Marshall Hathaway, J.J.M.; Dapkevicius, M.L.E.; Miller, A.Z.; Kooser, A.; Northup, D.E.; Jurado, V.; Fernandez, O.; Saiz-Jimenez, C.; Cheeptham, N. Actinobacterial diversity in volcanic caves and associated geomicrobiological interactions. Front. Microbiol. 2015, 6, 1342. [CrossRef] [PubMed]

23. Rusznyak, A.; Akob, D.M.; Nietzsche, S.; Eusterhues, K.; Totsche, K.U.; Neu, T.R.; Frosch, T.; Popp, J.; Keiner, R.; Geletneky, J.; et al. Calcite biomineralization by bacterial isolates from the recently discovered pristine karstic Herrenberg Cave. Appl. Environ. Microbiol. 2012, 78, 1157-1167. [CrossRef] [PubMed]

24. Riquelme, C.; Enes Dapkevicius, M.L.; Miller, A.Z.; Charlop-Powers, Z.; Brady, S.; Mason, C.; Cheeptham, N. Biotechnological potential of Actinobacteria from Canadian and Azorean volcanic caves. Appl. Microbiol. Biotechnol. 2017, 101, 843-857. [CrossRef] [PubMed]

25. Groth, I.; Vettermann, R.; Schuetze, B.; Schumann, P.; Saiz-Jimenez, C. Actinomycetes in karstic caves of northern Spain (Altamira and Tito Bustillo). J. Microbiol. Methods 1999, 36, 115-122. [CrossRef]

26. Jurado, V.; Laiz, L.; Rodriguez-Nava, V.; Boiron, P.; Hermosin, B.; Sanchez-Moral, S.; Saiz-Jimenez, C. Pathogenic and opportunistic microorganisms in caves. Int. J. Speleol. 2010, 39, 15-24. [CrossRef]

27. Madhaiyan, M.; Poonguzhali, S.; Lee, J.S.; Senthilkumar, M.; Lee, K.C.; Sundaram, S. Leifsonia soli sp. Nov., a yellow-pigmented actinobacterium isolated from teak rhizosphere soil. Int. J. Syst. Evol. Microbiol. 2010, 60, 1322-1327. [CrossRef] [PubMed]

28. An, S.Y.; Xiao, T.; Yokota, A. Leifsonia lichenia sp. Nov., isolated from lichen in Japan. J. Gen. Appl. Microbiol. 2009, 55, 339-343. [CrossRef] [PubMed]

29. Qiu, F.; Huang, Y.; Sun, L.; Zhang, X.; Liu, Z.; Song, W. Leifsonia ginsengi sp. nov., isolated from ginseng root. Int. J. Syst. Evol. Microbiol. 2007, 57, 405-408. [CrossRef] [PubMed]

30. Yassin, A.F.; Young, C.C.; Lai, W.A.; Hupfer, H.; Arun, A.B.; Shen, F.T.; Rekha, P.D.; Ho, M.J. Williamsia serinedens sp. nov., isolated from an oil-contaminated soil. Int. J. Syst. Evol. Microbiol. 2007, 57, 558-561. [CrossRef] [PubMed]

31. Yassin, A.F.; Hupfer, H. Williamsia deligens sp. nov., isolated from human blood. Int. J. Syst. Evol. Microbiol. 2006, 56, 193-197. [CrossRef] [PubMed]

32. Barron, S.K.; Murdock, C.A.; Blair, B.G.; Meade, M.E.; Barger, T.W. Analysis of bacterial diversity in soils from Blowing Spring cave (Lauderdale County, Al). J. Ala. Acad. Sci. 2010, 81, 1-10.

33. Busquets, A.; Fornos, J.J.; Zafra, F.; Lalucat, J.; Merino, A. Microbial communities in a coastal cave: Cova Des Pas de Vallgornera (Mallorca, western Mediterranean). Int. J. Speleol. 2014, 43, 205-216. [CrossRef]

34. Shabarova, T.; Pernthaler, J. Karst pools in subsurface environments: Collectors of microbial diversity or temporary residence between habitat types. Environ. Microbiol. 2010, 12, 1061-1074. [CrossRef] [PubMed]

35. Northup, D.E.; Barns, S.M.; Yu, L.E.; Spilde, M.N.; Schelble, R.T.; Dano, K.E.; Crossey, L.J.; Connolly, C.A.; Boston, P.J.; Natvig, D.O.; et al. Diverse microbial communities inhabiting ferromanganese deposits in Lechuguilla and Spider caves. Environ. Microbiol. 2003, 5, 1071-1086. [CrossRef] [PubMed]

36. Banerjee, S.; Joshi, S. Culturable bacteria associated with the caves of Meghalaya in India contribute to speleogenesis. J. Cave Karst Stud. 2016, 78, 144-157. [CrossRef]

37. Bastian, F.; Jurado, V.; Novakova, A.; Alabouvette, C.; Saiz-Jimenez, C. The microbiology of Lascaux Cave. Microbiology 2010, 156, 644-652. [CrossRef] [PubMed]

38. Kim, G.; Youn, H. Microbially induced calcite precipitation employing environmental isolates. Materials 2016, 9, 468. [CrossRef] [PubMed]

39. Adetutu, E.M.; Thorpe, K.; Shahsavari, E.; Bourne, S.; Cao, X.; Fard, R.M.N.; Kirby, G.; Ball, A.S. Bacterial community survey of sediments at Naracoorte Caves, Australia. Int. J. Speleol. 2012, 41, 137-147. [CrossRef]

40. Bhandari, V.; Ahmod, N.Z.; Shah, H.N.; Gupta, R.S. Molecular signatures for bacillus species: Demarcation of the Bacillus subtilis and Bacillus cereus clades in molecular terms and proposal to limit the placement of new species into the genus bacillus. Int. J. Syst. Evol. Microbiol. 2013, 63, 2712-2726. [CrossRef] [PubMed]

41. Lee, S.D. Paenibacillus cavernae sp. nov., isolated from soil of a natural cave. Int. J. Syst. Evol. Microbiol. 2016, 66, 598-603. [CrossRef] [PubMed] 
42. Pawlowski, A.C.; Wang, W.; Koteva, K.; Barton, H.A.; McArthur, A.G.; Wright, G.D. A diverse intrinsic antibiotic resistome from a cave bacterium. Nat. Commun. 2016, 7, 13803. [CrossRef] [PubMed]

43. Reddy, G.S.; Manasa, B.P.; Singh, S.K.; Shivaji, S. Paenisporosarcina indica sp. nov., a psychrophilic bacterium from a glacier, and reclassification of Sporosarcina antarctica Yu et al., 2008 as Paenisporosarcina antarctica comb. nov. And emended description of the genus Paenisporosarcina. Int. J. Syst. Evol. Microbiol. 2013, 63, 2927-2933. [CrossRef] [PubMed]

44. Krishnamurthi, S.; Bhattacharya, A.; Mayilraj, S.; Saha, P.; Schumann, P.; Chakrabarti, T. Description of Paenisporosarcina quisquiliarum gen. nov., sp. nov., and reclassification of Sporosarcina macmurdoensis reddy et al. 2003 as Paenisporosarcina macmurdoensis comb. nov. Int. J. Syst. Evol. Microbiol. 2009, 59, 1364-1370. [CrossRef] [PubMed]

45. Carmichael, M.J.; Carmichael, S.K.; Santelli, C.M.; Strom, A.; Brauer, S.L. Mn(II)-oxidizing bacteria are abundant and environmentally relevant members of ferromanganese deposits in caves of the upper Tennessee river basin. Geomicrobiol. J. 2013, 30, 779-800. [CrossRef]

46. Engel, A.S.; Paoletti, M.G.; Beggio, M.; Dorigo, L.; Pamio, A.; Gomiero, T.; Furlan, C.; Brilli, M.; Dreon, A.L.; Bertoni, R.; et al. Comparative microbial community composition from secondary carbonate (moonmilk) deposits: Implications for the Cansiliella. servadeii cave hygropetric food web. Int. J. Speleol. 2013, 42, 181-192. [CrossRef]

47. Cheng, C.; Wang, Q.; He, L.Y.; Huang, Z.; Sheng, X.F. Chitinophaga qingshengii sp. nov., isolated from weathered rock surface. Int. J. Syst. Evol. Microbiol. 2015, 65, 280-285. [CrossRef] [PubMed]

48. Lee, J.C.; Whang, K.S. Chitinophaga ginsengihumi sp. nov., isolated from soil of ginseng rhizosphere. Int. J. Syst. Evol. Microbiol. 2014, 64, 2599-2604. [CrossRef] [PubMed]

49. Yücel, S.; Yamaç, M. Selection of Streptomyces isolates from Turkish karstic caves against antibiotic resistant microorganisms. Pak. J. Pharm. Sci. 2010, 23, 1-6. [PubMed]

50. Cheeptham, N.; Higashiyama, T.; Phay, N.; Fukushi, E.; Matsuura, H.; Tomita, F.; Lumyong, S. An antifungal antibiotic (NCA-1) from Ellisiodothis inquinans L1588-A8, its identification and effects on growth of Saccharomyces cereviseae strain EC19. Ann. Rep. ICBiotech 1998, 20, 843-847.

(C) 2017 by the authors. Licensee MDPI, Basel, Switzerland. This article is an open access article distributed under the terms and conditions of the Creative Commons Attribution (CC BY) license (http://creativecommons.org/licenses/by/4.0/). 